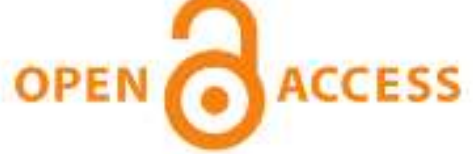

\section{International Journal of Applied Sciences and Biotechnology}

\section{A Rapid Publishing Journal}

ISSN 2091-2609

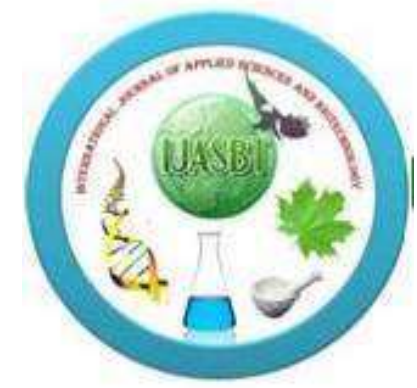

\section{Available online at:}

http://www.ijasbt.org

$\&$

http://www.nepjol.info/index.php/IJASBT/index

\section{Indexing and Abstracting}

CrossRef, Google Scholar, Global Impact Factor, Genamics, Index Copernicus, Directory of Open Access Journals, WorldCat, Electronic Journals Library (EZB), Universitätsbibliothek Leipzig, Hamburg University, UTS (University of Technology, Sydney): Library, International Society of Universal Research in Sciences (EyeSource), Journal Seeker, WZB, Socolar, BioRes, Indian Science, Jadoun Science, Jour-Informatics, Journal Directory, JournalTOCs, Academic Journals Database, Journal Quality Evaluation Report, PDOAJ, Science Central, Journal Impact Factor, NewJour, Open Science Directory, Directory of Research Journals Indexing, Open Access Library, International Impact Factor Services, SciSeek, Cabell's Directories, Scientific Indexing Services, CiteFactor, UniSA Library, InfoBase Index, Infomine, Getinfo, Open Academic Journals Index, HINARI, etc.

\section{CODEN (Chemical Abstract Services, USA): IJASKD}

Vol-2(4) December, 2014
Impact factor*: $\mathbf{1 . 4 2 2}$

Scientific Journal Impact factor\#: 3.419 Index Copernicus Value: $\mathbf{6 . 0 2}$

\section{SEM-Biotech}

Publishing

*Impact factor is issued by Universal Impact Factor. Kindly note that this is not the IF of Journal Citation Report (JCR). 
Research Article

\title{
IDENTIFICATION AND CHARACTERIZATION OF PANAMA WILT CAUSING FUNGAL ISOLATES TO MUSA PARADISIACA CV. PUTTABALE
}

\section{Venkatesh, Krishna Venkatarangaiah*, Pradeepa Krishnappa, Santosh Kumar S Rajanna, Nagaraja Deeplanaik, Mohan Kumar SP and Santhosh Kumar JU}

P.G. Department of Studies and Research in Biotechnology and Bioinformatics, Kuvempu University, Shankaraghatta - 577 451, India

*Correspondent author email: krishnabiotech2003@gmail.com

\begin{abstract}
Musa paradisiaca L. (Musaceae) cultivar 'Puttabale' is an indigenous banana commonly cultivated in the farmyards of Chitradurga, Davanagere, Chikmagalur and Shivamogga district of Karnataka. The fruits are valued for delicious taste. This banana cultivar is highly susceptible to Fusarium infection and the yield loss has estimated to 30-40\% at standing stage. The corm tissue of Musa paradisiaca cv. Puttabale showing typical panama wilt symptoms were collected from pathogen infected banana farmyard of Bhadravati, Sagara, Shikaripura, Holehonnur, Soraba, Thirthahalli, Gonibeedu and Lakkavalli regions of Shivamogga district of Karnataka. These infected corms were culture on PDA medium and examined carefully by morphological and molecular identification. Out of the eight fungal isolates, the colonies of fungal isolates collected from Bhadravati, Sagara, Holehonnur, Thirthahalli, Gonibeedu and Lakkavalli regions produced a dense white aerial mycelium that evenly spread on the growth medium similar to the colony texture of Fusarium species. Among these fungal isolates, the pathogen collected from Gonibeedu region showed the presence of sickle or rod shaped, four-celled macro conidiophores, round or oval shaped chlamydospores and the BLASTn search result showed $99 \%$ similarity with the sequences of Fusarium oxysporum f. sp. cubense (Foc). The only one fungal isolate showed the presence of actual panama wilt causing fungi.
\end{abstract}

Key words: Musa paradisiaca cv. Puttabale; Panama Wilt; Fusarium oxysporum f. sp. cubense.

\section{Introduction}

Bananas are monocotyledonous plants belongs to the family Musaceae and the genus Musa. Banana is grown in over 120 countries worldwide (Thangavelu \& Mustaffa, 2012) covering about 10 million hectares, with an annual world production estimated at 127 million tonnes. India alone produces 265.09 lakh tonnes of banana. The major banana producing states in India are Tamil Nadu, Gujarat, Maharashtra, Andhra Pradesh, Karnataka, Bihar and Madhya Pradesh. Tamil Nadu stood first in banana production. Its commercial importance is mainly limited to the tropical conditions, such as those popular in central, southern and North-Eastern India.

Musa paradisiaca L. (Musaceae) cultivar 'Puttabale' is an indigenous banana commonly cultivated in the farmyards of Chitradurga, Davanagere, Chikmagalur and Shivamogga of Karnataka. The plants grow to a height of $300 \mathrm{~cm}$ and girth of $50 \mathrm{~cm}$. They produce hardly 2-4 suckers per plant initially (Fig. 1A). It belongs to $A B$ genome and the fruits are valued for delicious taste. Each bunch has 7-10 hands, with 14-16 fruits or fingers per hand (Fig. 1B). Fruits are of medium size, yellow in color. Pulp is creamish and very sweet. It has a long shelf life. Even after the skin starts turning black, the pulp keeps good quality (Fig. 1C). This banana cultivar is highly susceptible to Fusarium infection and the yield loss has estimated to $30-40 \%$ at standing stage (Fig. 1D \& Fig. 1E).

Conventional method for the detection of $F$. oxysporum $\mathrm{f}$. sp. cubense provides inconsistent results and requires considerable knowledge of fungal taxonomy (Knowlton, 1993; Jarman \& Elliott, 2000). Molecular detection methods based on PCR are relatively faster, sensitive, highly specific, and accurate and results can be interpreted by personnel without taxonomic skills. These rDNA are highly stable and exhibit a mosaic of conserved and diverse regions within the genome (Hibbett, 1992). They also occur in multiple copies with up to 200 copies per haploid genome (Bruns et al., 1991; Yao et al., 1992) arranged in tandem repeats with each repeat consisting of the $18 \mathrm{~S}$ small subunit (SSU), the 5.8S, and the 28S large subunit (LSU) genes. Internal transcribed spacer (ITS) regions have been used successfully to generate specific primers capable of differentiating closely related fungal species (Bryan et al., 1995). The present study focused on the ITS regions of ribosomal genes for the identification of panama wilt causing fungal strains from Musa paradisiaca cv. Puttabale infected materials. 


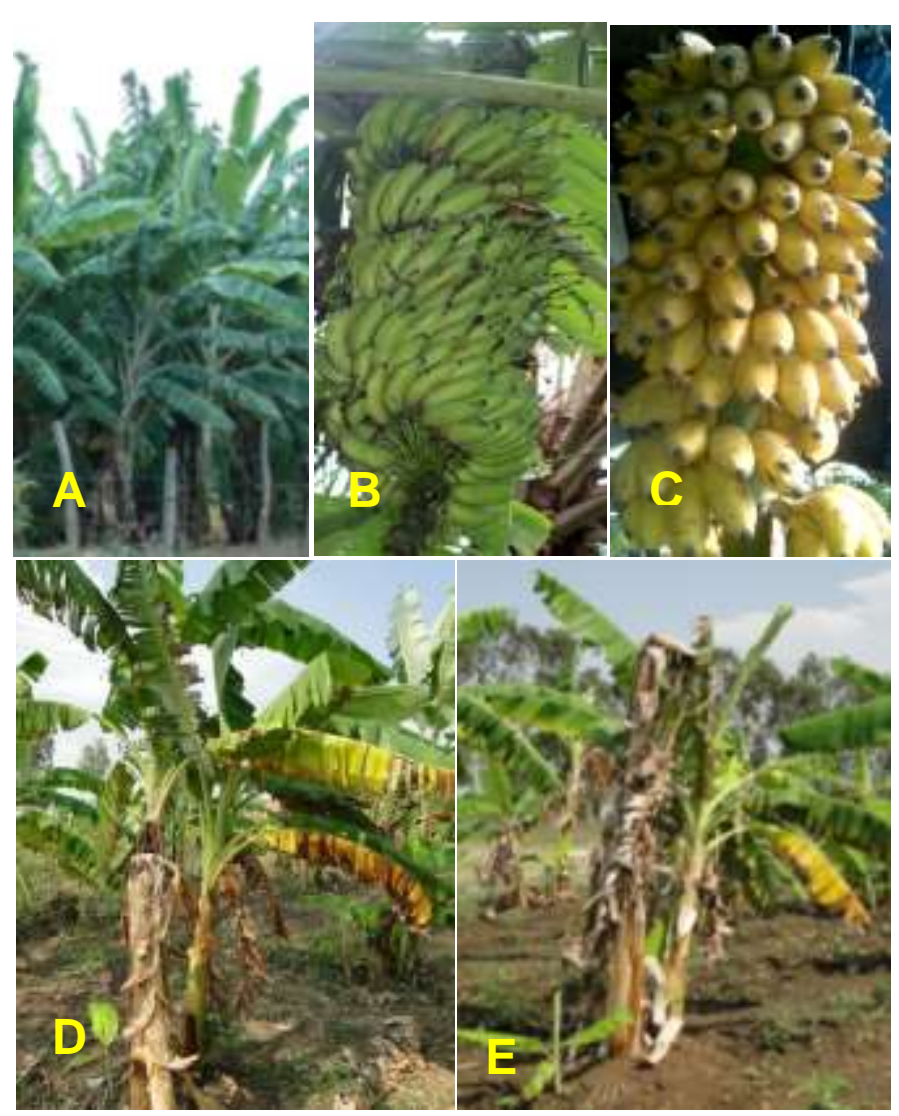

Fig. 1: A) The cultivar Puttabale plantation in farmyard of Shivamogga regions. B) Unripe banana fruits. C) Ripened fruits. D) \& E) the cultivar Puttabale infected with Fusarium wilt disease.

\section{Materials and methods}

\section{Isolation of Panama wilt fungi}

The corm tissue of Musa paradisiaca cv. Puttabale showing typical panama wilt symptoms were collected from pathogen infected banana farmyard of Bhadravathi, Sagara, Shikaripura, Holehonnur, Soraba, Thirthahalli, Gonibeedu and Lakkavalli regions of Shivamogga district of Karnataka. The tissue samples were cut into $10-15 \mathrm{~cm}$ length, washed in running tap water followed by sterile double distilled water and then cut into small cube shape pieces $(\leq 1 \mathrm{~cm})$. Tissue samples were disinfested with $70 \%$ alcohol for 30 s followed by three to four rises with sterilized double distilled water. The disinfested material was blot between sterile blotting papers. The tissues samples were aseptically transferred to half strength potato dextrose agar (PDA) medium amended with an streptomycin at $1.2 \mathrm{ml} / 240 \mathrm{ml} \mathrm{PDA}$, then incubate for $72 \mathrm{hrs}$ at $30^{\circ} \mathrm{C}$ under cool white fluorescent light. The fungal colonies were examine carefully by morphological and microscopic observation of hyphae and conidia characteristics (Nelson et al., 1983;. Burgess et al., 1994; Leslie \& Summerell, 2006). The appropriate stages were photographed using a JVC camera model KY-F55BE, with an image analyzer-SIS programme.
Extraction of DNA from Fusarium oxysporum $F$. sp. cubense

The DNA extracted from mycelium of seven-day-old culture grown on potato dextrose broth according to the method of Raeder and Broda (1985) with slight modifications by Chowdappa et al., (2003). Seven-day-old culture of fungal mycelium was harvested from broth by filtration through Whatman No.1 filter paper and damp dried. Dried Mycelium was ground into a fine powder in liquid Nitrogen and $50 \mathrm{mg}$ powder was taken in $1.5 \mathrm{ml}$ micro-centrifuge tubes. The ground mycelium was homogenized in $500 \mu 1$ extraction buffer $(200 \mathrm{mM}$ Tris; $\mathrm{pH}$ 8.0; $250 \mathrm{mM}$ EDTA; $0.5 \%$ SDS). To the homogenized mixture $500 \mu 1$ Phenol: Chloroform: Isoamylalcohol (25:24:1) was added and incubated at $60^{\circ} \mathrm{C}$ for 1 hour and centrifuged at $10,000 \mathrm{rpm}$ at $4^{\circ} \mathrm{C}$ for $30 \mathrm{~min}$. The upper aqueous layer was removed with a cut off pipette tip and transferred to a clean eppendroff tube. To the supernatant, $5 \mu 1$ ribonuclease solution was added and incubated at $37^{\circ} \mathrm{C}$ for $60 \mathrm{~min}$. An equal volume of chloroform: Isoamylalcohol (25:1) was added and centrifuged at $10,000 \mathrm{rpm}$ at $4{ }^{\circ} \mathrm{C}$ for $10-15 \mathrm{~min}$. The upper aqueous layer was collected and to it $3 / 4^{\text {th }}$ volume cold Isopropanol was added and centrifuged at $10,000 \mathrm{rpm}$ at $4^{\circ} \mathrm{C}$ for $2 \mathrm{~min}$. The pellet was dried overnight to remove traces of ethanol and dissolved in 40-100 $\mu 1 \mathrm{TE}$ buffer (10 mM, Tris ( $\mathrm{pH}-8.0) ; 1 \mathrm{mM}$ EDTA). DNA was stored at $-20^{\circ} \mathrm{C}$. DNA was quantified by gel method with Lambda DNA Hind III/ Eco RI double digest marker.

\section{PCR amplification and sequencing}

The genomic DNA of Fusarium cultures were subjected to PCR amplification by using ITS1 and ITS4 primers. Reaction mixture of PCR consisted of approximately $1 \mu 1$ of template DNA (50ng), $5 \mu$ l of 10x PCR buffer, $40 \mu$ l sterile distilled water, $1 \mu \mathrm{l} 2.0 \mathrm{mM}$ dNTPs, $0.5 \mu \mathrm{l}$ of $50 \mathrm{pM}$ primers ITS1 (5'-TCCGTAGGTGAACCTGCGG-3') and ITS4 (5'TTCCTCCGCTTATTGATATGC-3') and $0.25 \mu \mathrm{l}$ Taq polymerase $(5 \mathrm{U} / \mu \mathrm{l})$ (Merck Bio Sciences, India). In the initial thermal cycling condition denaturation was made at $95^{\circ} \mathrm{C}$ for $3 \mathrm{~min}$, followed by 35 cycles consisting of denaturation at $95^{\circ} \mathrm{C}$ for $30 \mathrm{~s}$, annealing at $55^{\circ} \mathrm{C}$ for $45 \mathrm{~s}$ and extension at $72^{\circ} \mathrm{C}$ for $1 \mathrm{~min}$, followed by a final extension of $72^{\circ} \mathrm{C}$ for $10 \mathrm{~min}$. PCR products were analysed by electrophoresis on 2\% (w/v) Agarose gel augmented with Ethidium bromide $(5 \mu \mathrm{g} / \mathrm{ml})$ in 1xTris Borate-EDTA buffer and visualized in UV transilluminator by Alpha imager EP (Alpha Innotech Corporation, USA). The amplified DNA product were eluted from gel and sequenced by Applied Biosystems DNA Analyzer 3037xl (Bio Serve Technologies, Hyderabad).

\section{Phylogenetic analysis}

Phylogenetic analyses were performed using amplified PCR product generated from ITS 1 and ITS 4 primers. The sequence similarity searches were performed by BLAST 
algorithm. MEGA 6 was used to generate a NJ phylogenetic tree that depicted the evolutionary relationships between eight fungal strains. The parameters used were JTT statistical model and 1000 replicates of bootstrapping analysis were done to determine the confidence level at the inner nodes of the topology (Saitou et al., 1987; Tamura et al., 2004; Tamura et al., 2013).

\section{Results and Discussion}

The cultivar, Puttabale is an endemic variety, known for its delicious taste and cultivated in most of the farmyards of Shivamogga, Chitradurga, Davanagere and Chikmagalur Districts of Karnataka. This crop is highly prone to Fusarium infection and affects the total loss of the crop at the standing stage. The disease control strategies such as,
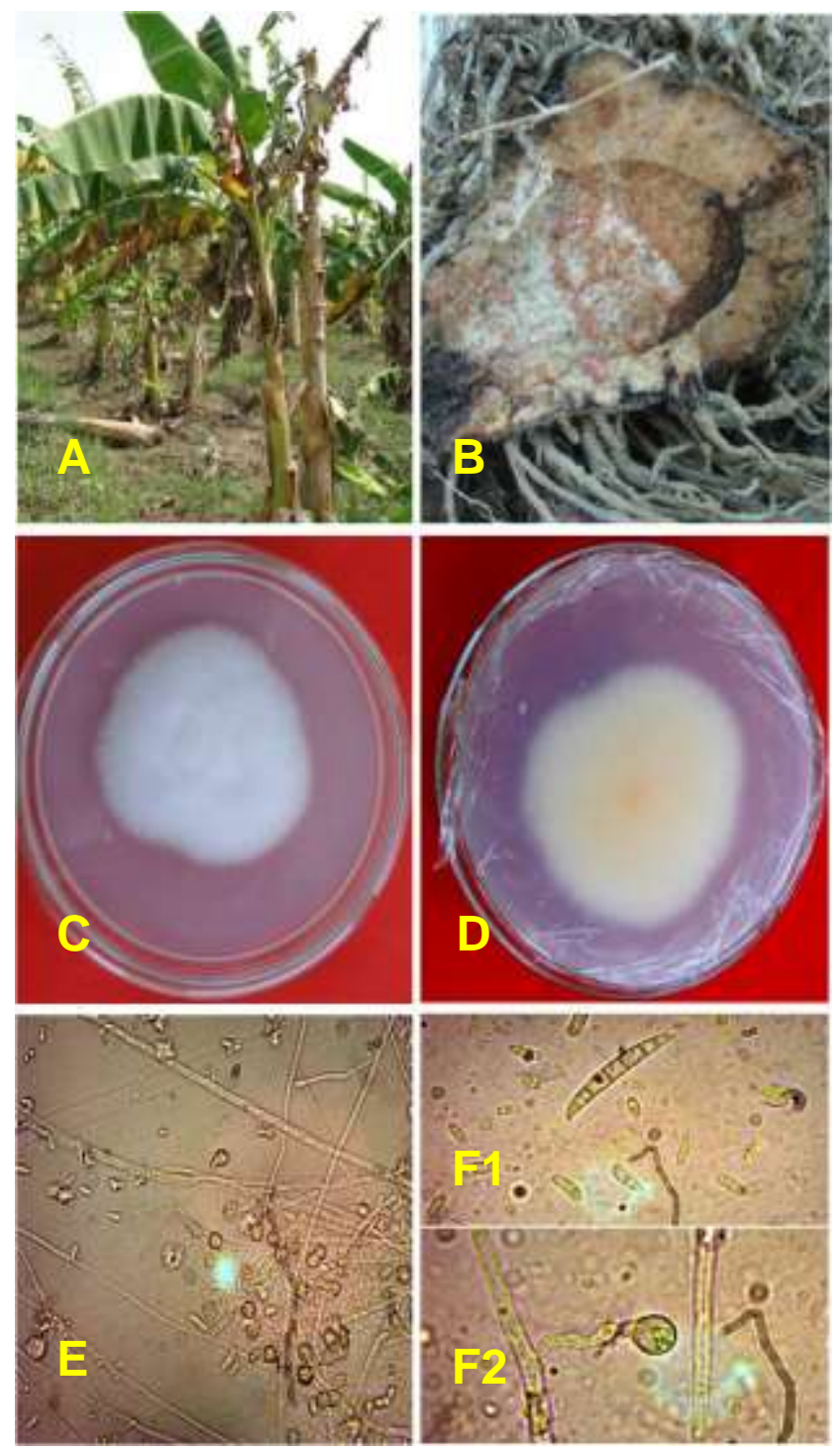

Fig. 2: Isolation of panama wilt fungi from the infected banana cv. Puttabale. A) The cultivar Puttabale infected with Foc. B) Colonization of Foc. C) Whitish thread like hairy colony of Foc. D) Production of pale pinkish color from Foc. E) Observation of microspores from Foc. F1) Sickle shaped macrospores and F2) Chylamadospores of Foc. quarantine and exclusion practices, flood fallowing, crop rotation and the use of organic amendments and use of fungicides are commonly but not satisfied (Moore et al., 1995). The symptoms of panama wilt is similar to other fungal infected diseases. It is very difficult to confirm panama wilt disease unless corroborated with morphological and molecular evidences.

\section{Morphological evaluation of fungal isolates}

The morphological characteristics was studied in the eight fungal isolates collected from the banana farmyard regions of Shivamogga District, Karnataka (Fig. 2A). The corm sections of infected plant showed the symptoms of panama wilt in the form of purplish or brownish black discoloration of the vascular bundles (Groenewald et al., 2006). This disrupts the translocation of nutrients leading to collapse foliage and cessation of the growth of the crown (Fig. 2B). The fungal isolates of shivamogga district namely, Bhadravati, Sagara, Holehonnur, Thirthahalli, Gonibeedu, Lakkavalli, Shikaripura and Soraba. Fungal isolates collected from Bhadravati, Sagara, Holehonnur, Thirthahalli, Gonibeedu and Lakkavalli regions produced a dense white aerial mycelium that was evenly spread on the growth medium (Fig. 2C). While, fungal isolates collected from Shikaripura and Soraba regions produced uneven colony margins with dense mycelia development. The growth rate of fungal isolates has measured in millimeter unit for every 24 hours after the inoculation. The growth rate of the fungal isolate collected from Gonibeedu region was $9.5 \mathrm{~mm}$ per day from the center of $90 \mathrm{~mm}$ Petri plate. After 10 days incubation, the mycelium produced pale pink to red pigmentation in the PDA medium (Fig. 2D). The remaining isolates does not exhibit pink pigmentation.

The microscopic examination of fungal isolates collected from Bhadravati, Sagara, Holehonnur, Thirthahalli, Gonibeedu and Lakkavalli regions showed the presence of septate much branched hyphae with abundant small, oval shaped and false head microconidia born on simple monophialides and the sickle shaped multicelluar macroconidia (Fig. 2E). These isolates exhibits morphological similarity with the Fusarium oxysporum (Beckman, 1987). While, isolates collected from Shikaripura and Soraba regions showed kidney shaped conidiospores and its mycelial structures similar to that of Colletotrichum species. The fungal isolate collected from Gonibeedu region exhibited the presence of sickle or rod shaped and four celled macrospores (Fig. 2F1) and round or oval shaped chlamydospores (Fig. 2F2). Ebbole and Sachs (1990) reported the microconidia are predominantly uninucleate and germinated poorly and variably. Macroconidia are multinucleate, produced abundantly and germinated rapidly. Chlamydospores were viable, asexually produced accessory spores resulting from structural modification of vegetative hyphal segment(s) or conidial cell possessing a thick wall (Schippers and Van Eck, 1981). 
Based on morphological and microscopic structure, this isolates identified as Fusarium oxysporum f. sp. cubense and it showed similarity with the panama wilt pathogen.

\section{DNA sequencing of fungal isolates}

This study also focused on DNA sequencing and phylogenetic relationship between the Foc. The highly conserved ribosomal DNA (rDNA) and the internal transcribed spacer region (ITS) are the most used and easy targets for the development of PCR based detection techniques (Wu et al., 2002; Kullnig-Gradinger et al., 2002).

\section{i) DNA extraction and quantification}

The DNA extracted from the mycelium of isolates showed good quality of integrity on $0.8 \%$ agarose gel. Gel based method was used to quantify the DNA using lambda DNA as a standards (Lane ABCD\&E, 75ng - 250ng). The DNA was visualized under ultra-violet light. The concentration of DNA was ranged from 50- $150 \mathrm{ng} / \mu \mathrm{l}$ (Lanes 1-8 of Fig. 3A). Samples with DNA bands that showed high molecular weights and brightness were selected for PCR analysis.
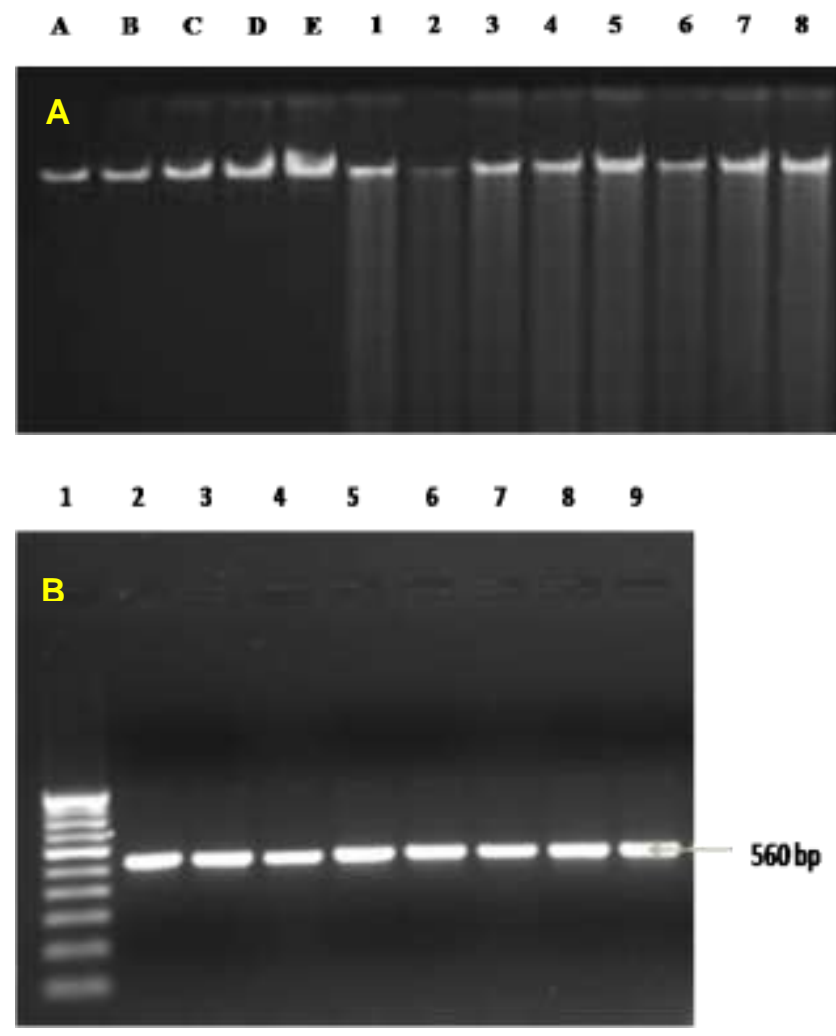

Fig. 3: DNA Quantification and PCR amplification

A) Quantification of DNA (Lamda DNA Standards A- $75 \mathrm{ng}$, B$100 \mathrm{ng}, \mathrm{C}-150 \mathrm{ng}, \mathrm{D}-200 \mathrm{ng}, \mathrm{E}-250 \mathrm{ng})$ Lane 1: $80 \mathrm{ng}$; Lane 2: $60 \mathrm{ng}$; Lane 3: $100 \mathrm{ng}$; Lane 4: 100ng; Lane 5: $180 \mathrm{ng}$; Lane 6: $75 \mathrm{ng}$; Lane 7: $150 \mathrm{ng}$; Lane 8: $150 \mathrm{ng}$.

B) PCR amplification of ITS 1 and ITS 4 products Lane 1: $100 \mathrm{bp}$ ladder; Lane 2- 9: eight fungal strains. (2-BHA; 3-SAG; 4-SHI; 5-HOL; 6-SOR; 7-THI; 8-GON; 9-LAK)

\section{ii) DNA sequencing}

The $50 \mathrm{ng}$ of DNA was subjected for PCR amplification using ITS1 and ITS4 primer. The PCR reaction generates an approximately $540-570 \mathrm{bp}$ amplification product. The amplification product was visualized on $2 \%(\mathrm{w} / \mathrm{v})$ agarose gel under ultra-violet light (Fig. 3B). The amplified DNA product were eluted from gel and subjected for sequencing. The amplified sequences were compared with the available sequences in the GenBank at the NCBI website.

\section{iii) BLASTn search}

By comparing the sequences of the ITS region to the sequences deposited in GenBank, six isolates showed homology with at least $99 \%$ similarity to Fusarium and two isolates showed $100 \%$ similarity with Colletotrichum species. The report of Druzhinina and Kubicek (2004) also revealed that GenBank database contain many sequences of Fusarium isolates which may have been considered for identification. The BLASTn search analysis of ITS rDNA sequence on the NCBI website indicated that the PCR amplified product of the fungal isolate collected from Bhadravati region showed $100 \%$ similarity with sequences of Fusarium solani 54 strain. Its Accession number is JX897000.1 and exhibiting internal transcribed spacer-1, partial sequence; 5.8S ribosomal RNA gene and internal transcribed spacer-2, complete sequence; and $28 \mathrm{~S}$ ribosomal RNA gene, partial sequence. In the isolates of Sagara region, the blasted results showed $99 \%$ similarity for Fusarium oxysporum f. sp. psidii isolate Fop164 18S ribosomal RNA gene, partial sequence with an Accession number KC357564.1. Similarly, the blasted results of fungal isolates of Holehonnur region showed $98 \%$ similarity for Fusarium oxysporum isolate F2 18S ribosomal RNA gene, partial sequence with Accession number KJ026700.1; the isolates of Lakkavalli region showed 99\% similarity to Fusarium sp. SK12YW6G1 18S ribosomal RNA gene, partial sequence with Accession number EU807939.1 and the isolates of Thirthahalli region showed a of $99 \%$ similarity with Fusarium sp. Papaya118S ribosomal RNA gene, partial sequence with accession number EU707572.1.

The isolates of Shikaripura region showed a $100 \%$ similarity with Colletotrichum gloeosporioides; voucher KUAB3 CGDA internal transcribed spacer 1, partial sequence with Accession number KF303142.1. The isolates of Soraba region showed there was a similarity of $100 \%$ with Colletotrichum capsici isolate KUAB1CC3 18S ribosomal RNA gene, partial sequence with accession number JX910365.1. The blasted result belongs to the fungal isolates of Gonibeedu region showed $99 \%$ similarity with the sequences of Fusarium oxysporum f. cubense isolate F-py-08 18S ribosomal RNA gene, partial sequence with accession number EU780660.1. The morphological characteristics of the mycelium, conidial nature and the etiology of the diseases of the banana crop in this region is similar to the panama wilt pathogen Fusarium oxysporum $\mathrm{f}$. sp. cubense. 


\section{iv) Phylogenetic analysis}

The sequences for each organism obtained from independent PCR has found to be consistent only minimal nucleotide differences between them. Phylogenetic trees were generated by using four different methods (UPGMA, NJ, MP and Minimum Evolution) based on ITS rDNA sequences of Fusarium sps. obtained from various locations illustrating their possible phylogenetic relationships at intraspecific level. The tree generated by UPGMA method was considered because of its consistency in topology. The phylogenic trees were constructed based on nucleotide sequences of eight fungal strains. Evolutionary relationships of 8 fungal isolates are shown in Fig. 4. The evolutionary history was inferred using the NeighborJoining method. The optimal tree with the sum of branch length $=0.40364803$ is shown. The tree is drawn to scale, with branch lengths in the same units as those of the evolutionary distances used to infer the phylogenetic tree. The evolutionary distances were computed using the
Maximum Composite Likelihood method and are in the units of the number of base substitutions per site. The analysis involved 8 nucleotide sequences. Codon positions included were $1 \mathrm{st}+2 \mathrm{nd}+3 \mathrm{rd}+$ Noncoding. All positions containing gaps and missing data were eliminated. There were a total of 436 positions in the final dataset. Evolutionary analyses was performed using MEGA6. The molecular characterization fungal isolates collected from banana farmyards of above said regions revealed that the existence of panama wilt pathogen Fusarium oxysporum $\mathrm{f}$. sp. cubense was noticed only in Gonibeedu region of Shivamogga District. Whereas, in the other regions the spoil of the banana crop was not due to panama wilt and it may due to the synchronous effect of Fusarium species with other pathogenic fungi. These experiments showed that the isolates are not restricted to different races of Fusarium oxysporum f. sp. cubense and that a specific molecular marker is needed to differentiate the races.
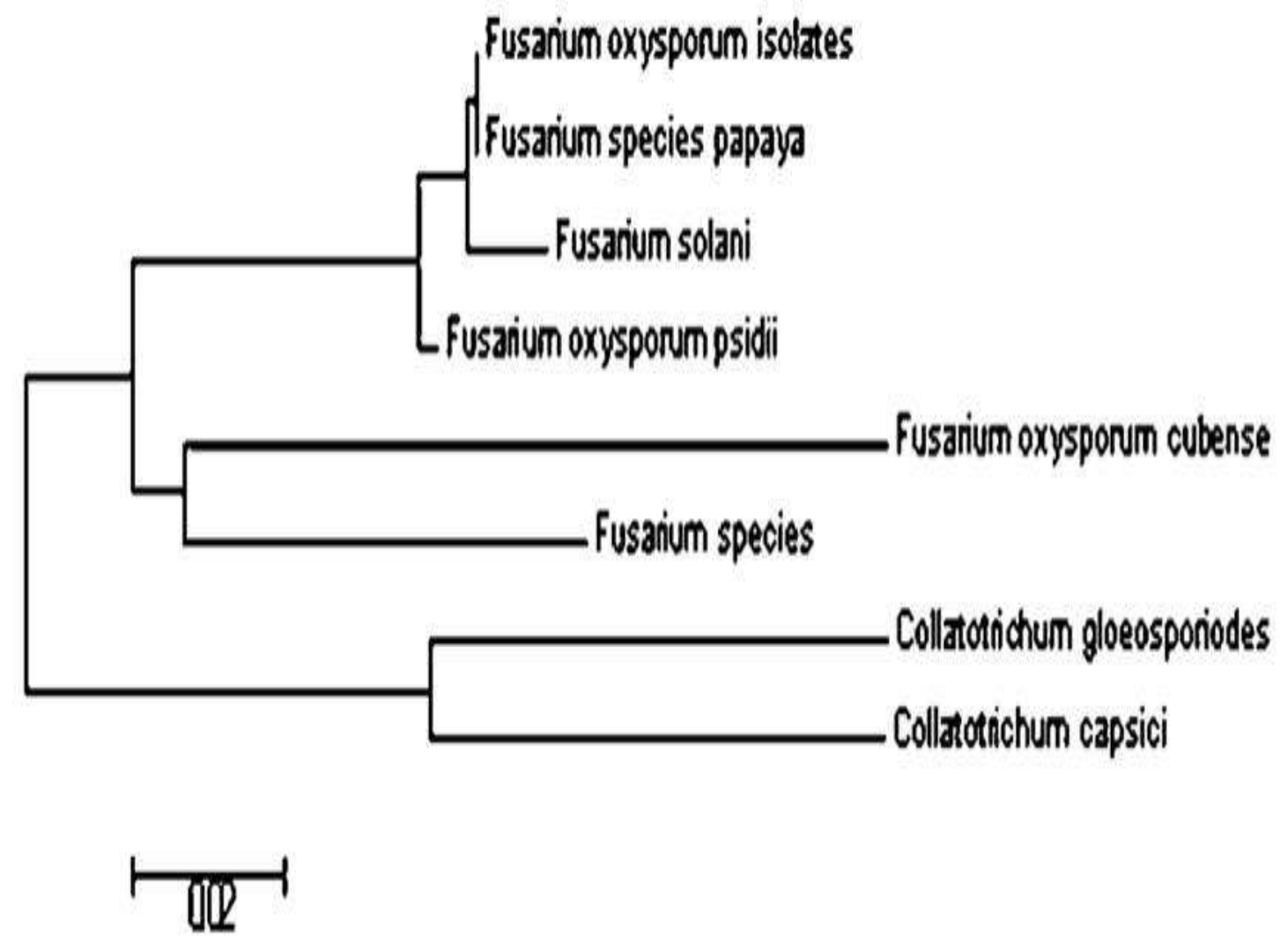

Fig. 4: Evolutionary relationships of eight fungal taxa isolated in infected cultivar Puttabale from banana farmyards. 


\section{Acknowledgement}

The authors thank to University Grant Commission (UGC), New Delhi, for financial support, the Registrar, Kuvempu University for encouragement, and Chairman, Department of Biotechnology and Bioinformatics, Kuvempu University for laboratory assistance and facilities.

\section{References}

Beckman CH (1987) The nature of wilt diseases of plants. American Phytopathological Society, St Paul, Minnesota, USA.

Bruns TD, White TJ, and Taylor JW (1991) Fungal molecular systematics. Annual Review of Ecology Systematics. 525564. DOI: 10.1146/annurev.es.22.110191.002521.

Bryan GT, Daniels MJ, and Osbourn AE (1995) Comparison of fungi within the Gaeumannomyces-Phialophora complex by analysis of ribosomal DNA sequences. Applied and Environmental Microbiology. 61: 681-689.

Burgess LW, Summerell BA, Bullock S, Gott KP, and Back house D (1994) Laboratory manual for Fusarium research. Fusarium Research Laboratory, The University of Sydney, Australia.

Chowdappa P, Brayford D, Smith J, and Flood J (2003) Molecular discrimination of Phytophthora isolates on cocoa and their relationship with coconut, black pepper and bell pepper isolates based on rDNA repeat and AFLP fingerprints. Current science. 84: 1235-1238.

Druzhinina I, and Kubicek CP (2005) Species concepts and biodiversity in Trichoderma and Hypocrea: from aggregate species to species clusters? Journal of Zhejiang University. Science B. 6: 100-112. DOI: 10.1631/jzus.2005.B0100.

Ebbole D, and Sachs MS (1990) A rapid and simple method for isolation of Neurospora crassa homokaryons using microconidia. Fungal Genet. Newsl. 37: 17-18.

Groenewald S, Van den Berg N. Marasas WFO, and Viljoen A (2006) Biological, physiological and pathogenic variation in a genetically homogenous population of Fusarium oxysporum f. sp. cubense. Australasian Plant Pathology. 35: 401-409. DOI: 10.1071/AP06041.

Hibbett DS (1992) Ribosomal RNA and fungal systematics. Transactions of the Mycological Society of Japan. 33: 533-556.

Jarman SN, and Elliott NG (2000) DNA evidence for morphological and cryptic Cenozoic speciations in the Anaspididae, 'living fossils' from the Triassic. Journal of Evolutionary Biology. 13: 624-633. DOI: 10.1046/j.14209101.2000.00207.x.
Knowlton N (1993) Sibling species in the sea. Annual Review of Ecology and Systematics. 189-216. DOI: 10.1146/annurev.es.24.110193.001201.

Kullnig-Gradinger CM, Szakacs G, and Kubicek CP (2002) Phylogeny and evolution of the genus Trichoderma: a multigene approach. Mycological Research. 106: 757767. DOI: $10.1017 /$ S0953756202006172.

Leslie JF, and Summerell BA (2006) The Fusarium laboratory manual. Blackwell publishing. DOI: $10.1002 / 9780470278376$.

Moore NY, Bentley S, Pegg KG, and Jones DR (1995) Fusarium Wilt of Bananas. Musa Disease Fact Sheet No. 5. INIBAP.

Nelson PE, Toussoun TA, and Marasas WFO (1983) Fusarium species: an illustrated manual for identification. 193.

Raeder U, and Broda P (1985) Rapid preparation of DNA from filamentous fungi. Letters in Applied Microbiology. 1: 1720. DOI: 10.1111/j.1472-765X.1985.tb01479.x.

Saitou N, and Nei M (1987) The neighbor-joining method: a new method for reconstructing phylogenetic trees. Molecular biology and evolution. 4: 406-425.

Schippers B, and Van Eck WH (1981) Formation and survival of chlamydospores in Fusarium. Fusarium: disease, biology, and taxonomy. Penn State University Press, University Park. 250-260.

Tamura K, Nei M, and Kumar S (2004) Prospects for inferring very large phylogenies by using the neighbor-joining method. Proceedings of the National Academy of Sciences of the United States of America. 101: 11030-11035. DOI: 10.1073/pnas.0404206101.

Tamura K, Stecher G, Peterson D, Filipski A, and Kumar S (2013). MEGA6: molecular evolutionary genetics analysis version 6.0. Molecular biology and evolution. 30: 2725-2729. DOI: 0.1093/molbev/mst197.

Thangavelu R, and Mustaffa MM (2012) Current advances in the Fusarium wilt disease management in banana with emphasis on biological control. Plant Pathology. In Tech. 273-298.

Wu Z, Wang XR, and Blomquist G (2002) Evaluation of PCR primers and PCR conditions for specific detection of common airborne fungi. Journal of Environmental Monitoring. 4: 377-382. DOI: 10.1039/b200490a.

Yao C, Frederiksen RA, and Magill CW (1992) Length heterogeneity in ITS 2 and the methylation status of CCGG and GCGC sites in the rRNA genes of the genus Peronosclerospora. Current genetics. 22: 415-420. DOI:10.1007/BF00352443. 